\title{
Toll-Like Receptor-9 Agonist Inhibits Airway Inflammation, Remodeling and Hyperreactivity in Mice Exposed to Chronic Environmental Tobacco Smoke and Allergen
}

\author{
Dae Jin Song ${ }^{a}$ b Myung Goo Min ${ }^{a}$ Marina Miller ${ }^{a}$ Jae Youn Cho ${ }^{a}$ \\ Hye Yung Yum ${ }^{a, c}$ David H. Broide ${ }^{a}$ \\ ${ }^{a}$ Department of Medicine, University of California San Diego, San Diego, Calif., USA; ${ }^{b}$ Department of Pediatrics, \\ College of Medicine, Korea University, and ' A Atopy Clinic, Seoul Medical Center, Seoul, Korea
}

\section{Key Words}

Toll-like receptor-9 - Airway hyperreactivity · Airway inflammation $\cdot$ Airway remodeling $\cdot$ Eosinophils

\begin{abstract}
Background: As passive environmental tobacco smoke (ETS) exposure in nonsmokers can increase both asthma symptoms and the frequency of asthma exacerbations, we utilized a mouse model, in which ovalbumin (OVA) + ETS induce significantly increased levels of eosinophilic airway inflammation and remodeling compared to either stimulus alone, to determine whether a Toll-like receptor-9 (TLR-9) agonist could reduce levels of airway inflammation, airway remodeling and airway hyperreactivity (AHR). Methods: Mice treated with or without a TLR-9 agonist were sensitized to OVA and challenged with OVA + ETS for 1 month. AHR to methacholine was assessed in intubated and ventilated mice. Lung Th2 cytokines and TGF- $\beta_{1}$ were measured by ELISA. Lungs were processed for histology and immunohistology to quantify eosinophils, mucus, peribronchial fibrosis and smooth muscle changes using image analysis. Results: Administration of a TLR-9 agonist to mice coexposed to chronic ETS and chronic OVA allergen significantly reduced levels of eosinophilic airway inflammation, mucus production, peribronchial fibrosis, the thickness of the peribronchial smooth muscle lay-
\end{abstract}

er, and AHR. The reduced airway remodeling in mice treated with the TLR-9 agonist was associated with significantly reduced numbers of peribronchial MBP+ and peribronchial TGF- $\beta_{1}+$ cells, and with significantly reduced levels of lung Th2 cytokines [interleukin-5 and interleukin-13] and TGF- $\beta_{1}$. Conclusion: These studies demonstrate that TLR-9-based therapies inhibit airway inflammation, remodeling and AHR in mice coexposed to ETS and allergen who exhibit enhanced airway inflammation and remodeling.

Copyright $\odot 2009$ S. Karger AG, Basel

\section{Introduction}

Asthma is a disease characterized by airway inflammation and airway hyperreactivity (AHR) [1]. A variety of environmental triggers can aggravate asthma including allergens, viruses, pollutants and tobacco smoke [1]. In terms of tobacco smoke exposure acting as a trigger for asthma, several studies have demonstrated that exposure to either high levels of tobacco smoke in active smokers [2-4] or low levels of tobacco smoke exposure in nonsmokers passively exposed to environmental tobacco smoke (ETS) [5-7] are associated with adverse asthma outcomes including increased prevalence of asthma, increased severity of asthma symptoms, increased frequen-

\section{KARGER}

๑ 2009 S. Karger AG, Basel

Fax +4161306 1234

E-Mail karger@karger.ch

www.karger.com
Accessible online at:

www.karger.com/iaa
Correspondence to: Dr. David Broide

University of California San Diego

Biomedical Sciences Building, Room 5090

9500 Gilman Drive, La Jolla, CA 92093-0635 (USA)

Tel. +1 858534 2374, Fax +1 858534 2110, E-Mail dbroide@ucsd.edu 
cy of asthma medication use and increased emergency room visits by asthmatic children. The importance of ETS exposure to asthma is further suggested from recent gene association studies demonstrating a link between a region on chromosome 17q21, combined with ETS, and asthma [8]. Experimental ETS challenge studies in humans also indicate that such exposure has adverse effects on airflow and/or airway responsiveness in asthma [9, 10]. Thus, to reduce the adverse impact of ETS on asthma requires strategies that include reducing the number of smokers and, consequently, of ETS-exposed asthmatics. However, in the USA, although $45 \%$ of smokers each year make an attempt to quit, less than $5 \%$ of the general population are successful [11]. As up to $68 \%$ of nonsmoking children with asthma in the inner cities of the USA are also exposed to ETS as assessed by salivary cotinine levels [7], more immediate strategies are needed to reduce adverse asthma outcomes in ETS-exposed asthmatics in addition to the long-term strategy of reducing the number of smokers.

Studies in mouse models suggest a potential immunologic mechanism for the interaction of ETS and allergen resulting in adverse asthma outcomes. For example, studies by our group [12] and others $[13,14]$ have demonstrated that exposure of mice to the combination of ETS and ovalbumin (OVA) allergen induces significantly higher levels of Th2 cytokines, eosinophilic airway inflammation, mucus expression, peribronchial fibrosis, thickness of the smooth muscle layer, and AHR compared to levels induced by exposure to either OVA alone or ETS alone. As recent studies suggest that inhaled and oral corticosteroids, currently our most effective anti-inflammatory therapies in asthma, are not as effective in asthmatics who smoke [15-18], there is a need to identify novel therapeutic interventions that inhibit $\mathrm{Th} 2 \mathrm{immune}$ responses both in asthmatics exposed and not exposed to ETS. We have previously demonstrated that administration of a Toll-like receptor-9 (TLR-9) ligand [i.e. immunostimulatory sequences (ISS) of DNA containing a CpG motif] inhibits Th2 cytokine responses [19], eosinophilic airway inflammation $[19,20]$, airway remodeling [21-24] and AHR [19] in mouse models of asthma. In addition, conjugation of the TLR-9 ligand to the major ragweed allergen Amb a 1 significantly reduces seasonal ragweed rhinitis symptoms in ragweed-allergic human subjects [25]. Based on the ability of TLR-9 ligands to inhibit Th2 cytokine responses [19], as well as on our demonstration that mice coexposed to ETS and OVA allergen have enhanced $\mathrm{Th} 2$ cytokine responses [12], we have investigated in the present study whether a TLR-9 ligand would be ef- fective in reducing the enhanced airway inflammation, remodeling and AHR in mice induced by chronic coexposure to ETS and allergen.

\section{Methods}

Therapeutic Intervention with TLR-9 Ligand in Chronic ETS + OVA-Exposed Mice

In this study we have examined whether administration of a TLR-9 ligand (i.e. ISS) inhibits airway inflammation, airway remodeling and AHR in mice exposed to chronic ETS in combination with chronic OVA allergen for 1 month. Different groups of 8 - to 10 -week-old BALB/c mice (12 mice/group; The Jackson Laboratory, Bar Harbor, Me., USA) were chronically exposed to ETS as well as to either no OVA, OVA or OVA + ISS. As controls we also included mice not exposed to ETS (no OVA and OVA). The results of an OVA + corticosteroid intervention in ETS + OVAexposed mice are reported elsewhere [26], and the present study focuses on the effect of ISS on airway inflammation, airway remodeling, and AHR in ETS-exposed mice. Both intervention studies (ISS or corticosteroid) used the same control groups to limit the number of control mice required for these experiments. The group of ETS-exposed mice that received the OVA + ISS were administered intraperitoneally endotoxin-free phosphorothioate ISS-oligodeoxynucleotides (5'-TGACTGTGAACGTTCGAGATGA-3'; Trilink, San Diego, Calif., USA; $100 \mu \mathrm{g}$ in $100 \mu \mathrm{l}$ of sterile, endotoxin-free PBS), starting 1 day before the first intranasal OVA challenge and then continued every other week for the duration of the 1-month period of combined ETS exposure and twiceweekly OVA challenges. Previous studies in our laboratory have demonstrated that ISS inhibits OVA-induced eosinophilic inflammation, airway remodeling and AHR when administered 1 day before OVA challenge [19, 21-24], and that this inhibitory effect lasts at least 4 weeks [27].

\section{Chronic ETS + Chronic OVA Exposure}

We have previously demonstrated that chronic ETS exposure alone does not increase airway inflammation, airway remodeling or AHR in mice [12]. In contrast, coexposure of mice to chronic ETS and chronic OVA allergen significantly increases levels of eosinophilic inflammation, airway remodeling and AHR as compared to mice exposed to chronic OVA allergen with no ETS exposure [12].

Chronic ETS Exposure (fig. 1). Three groups of mice (no OVA, OVA and OVA + ISS) were exposed to chronic ETS (side-stream smoke from 6 cigarettes/day each administered over approximately 5 min with a 15 -min break between cigarettes, 5 days/ week) generated by burning $2 \mathrm{R} 4 \mathrm{~F}$ reference cigarettes $(2.45 \mathrm{mg}$ nicotine/cigarette; Tobacco Research Institute, University of Kentucky, Lexington, Ky., USA) using a smoking machine (McChesney-Jaeger CSM-SSM Single Cigarette Machine, CH Technologies USA, Inc., Westwood, N.J., USA) regulated by programmable controls provided with JASPER Windows 9x/2000 software over RS-232 communication ports (CH Technologies USA, Inc.) as previously described in this laboratory [12]. Each smoldering cigarette is puffed for approximately $2 \mathrm{~s}$, once every $25 \mathrm{~s}$, for a total of 12 puffs/cigarette, at a flow rate of 5 liters $/ \mathrm{min}$. The outflow from the smoking machine was adjusted to mimic an exposure to 


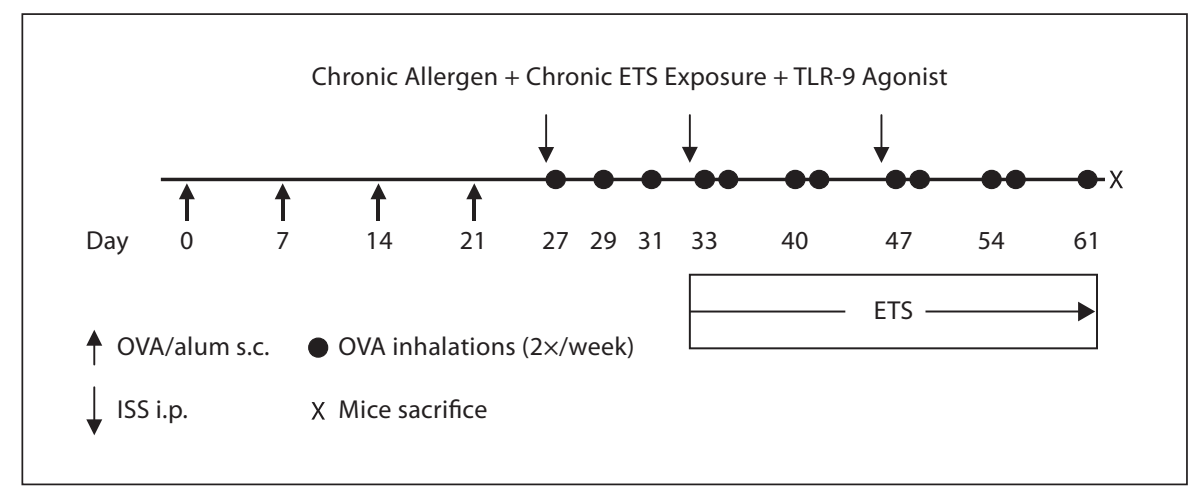

Fig. 1. Mice were immunized s.c. on days $0,7,14$ and 21 with OVA (arrows pointing up). Intranasal OVA challenges were administered on days 27, 29 and 31, and then repeated twice a week for 1 month. Different groups of mice were either administered ETS alone or ETS in combination with OVA challenges. ETS was started on day 33 (after mice had been sensitized and challenged on 3 occasions with intranasal OVA). The ETS was continued 5 days/ week for 1 month. ISS was administered on 3 occasions i.p. (arrows pointing down) starting on day 26 with repeat doses on days 32 and 46 . The mice were sacrificed $24 \mathrm{~h}$ after the final OVA challenge on day 60 and BAL fluid and lungs were analyzed.
ETS by producing a mixture of room air (98\%) and mainstream smoke (2\%). The mice were exposed to the ETS in a 12-port, noseonly, directed flow inhalation exposure system (Jaeger-NYU 12 port). Nose ports were monitored for total suspended particulates which we have previously reported to be $173 \pm 5.3 \mu \mathrm{g} / \mathrm{m}^{3}$ using a gravimetric method [12]. All animal experimental protocols were approved by the University of California, San Diego Animal Subjects Committee.

Chronic OVA Protocol (fig. 1). In these studies, mice were immunized subcutaneously on days $0,7,14$ and 21 with $25 \mu \mathrm{g}$ of OVA (OVA, grade V; Sigma Chemicals, St. Louis, Mo., USA) adsorbed to $1 \mathrm{mg}$ of alum (Aldrich) in $200 \mu \mathrm{l}$ normal saline as previously described [28]. OVA-challenged mice received intranasal OVA challenges on days 27, 29 and 31 under isoflurane (Vedco, Inc., St. Joseph, Mo., USA) anesthesia, which were then repeated twice a week for 1 month. The no-OVA age- and sex-matched control mice were sensitized but not challenged with OVA during the 1-month study. The groups of mice that were exposed to ETS had their first ETS exposure on day 33 after they had been sensitized with OVA subcutaneously, and received intranasal OVA challenges on days 27, 29 and 31 as previously described in this laboratory [28]. Chronic ETS was continued daily for the subsequent 1-month period of twice-weekly intranasal OVA challenges.

\section{Processing of Lungs for Immunohistology}

The mice were sacrificed $24 \mathrm{~h}$ after the final chronic OVA and/ or chronic ETS challenge and bronchoalveolar lavage (BAL) fluid and lungs were analyzed as previously described [28]. The lungs in the different groups of mice were equivalently inflated with an intratracheal injection of a similar volume of $4 \%$ paraformaldehyde solution (Sigma Chemicals) to preserve the pulmonary architecture. These lungs were then processed as a batch for either histologic staining or immunostaining under identical conditions. Stained and immunostained slides were all quantified under identical light microscope conditions, including magnification $(\times 20)$, gain, camera position and background illumination. The quantita- tive histologic and image analysis of all coded slides was performed by research associates blinded to the coding of all the slides.

$B A L$ and Peribronchial Eosinophils. Total BAL eosinophil counts and the number of peribronchial $\mathrm{MBP}+$ cells were quantitated as previously described [28]. In brief, lung sections were processed for MBP immunohistochemistry using an anti-mouse MBP antibody (kindly provided by James Lee, $\mathrm{PhD}$, Mayo Clinic, Scottsdale, Ariz., USA). The number of individual cells staining positive for MBP in the peribronchial space was counted using a light microscope. Results are expressed as the number of peribronchial cells staining positive for MBP/bronchiole with 150$200 \mu \mathrm{m}$ of internal diameter. At least 10 bronchioles were counted in each slide.

Mucus. The number of PAS-positive and PAS-negative airway epithelial cells in individual bronchioles were counted as previously described in this laboratory [28]. At least 10 bronchioles were counted in each slide. Results are expressed as the percentage of PAS+ cells/bronchiole which is calculated from the number of PAS+ epithelial cells/bronchus divided by the total number of epithelial cells of each bronchiole.

Peribronchial Fibrosis. The area of peribronchial trichrome staining in the paraffin-embedded lungs was outlined and quantified using a light microscope (Leica DMLS; Leica Microsystems, Inc., New York, N.Y., USA) attached to an image analysis system (Image-Pro Plus; Media Cybernetics, Bethesda, Md., USA) as previously described [28]. Results are expressed as the area of trichrome staining/ $\mu \mathrm{m}$ length of the basement membrane of bronchioles 150-200 $\mu \mathrm{m}$ of internal diameter.

Peribronchial TGF- $\beta_{1}+$ Cells. The number of peribronchial cells expressing TGF- $\beta_{1}$ were assessed in lung sections processed for immunohistochemistry using an anti-TGF- $\beta_{1}$ primary antibody (Santa Cruz, Calif., USA), the immunoperoxidase method and image analysis quantitation as previously described [28]. Results are expressed as the number of TGF- $\beta_{1}+$ cells/bronchus [28]. 


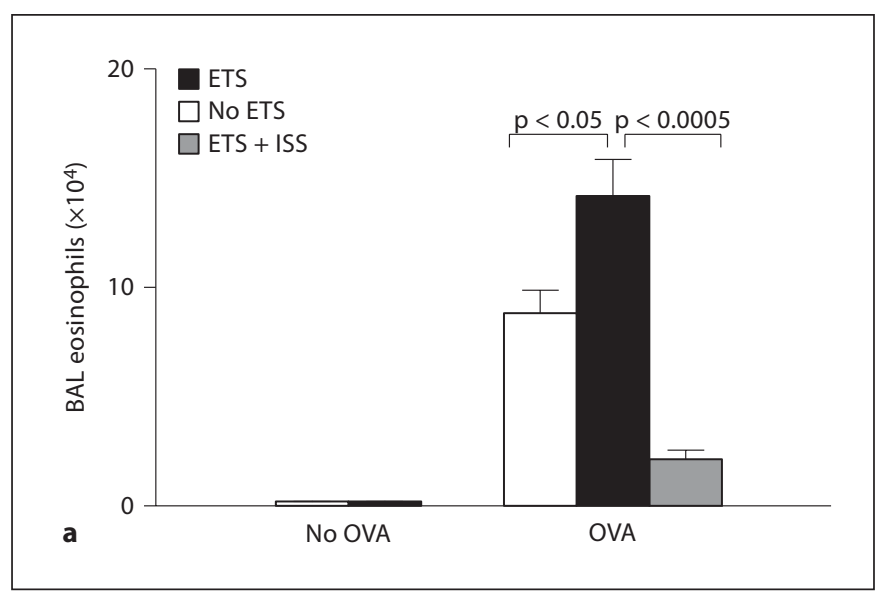

Fig. 2. Eosinophils were quantitated by either Wright-Giemsa staining in BAL fluid (a) or by immunostaining lung sections with anti-MBP antibody (b). In ETS-exposed mice challenged with OVA, ISS significantly reduced the number of BAL eosino-

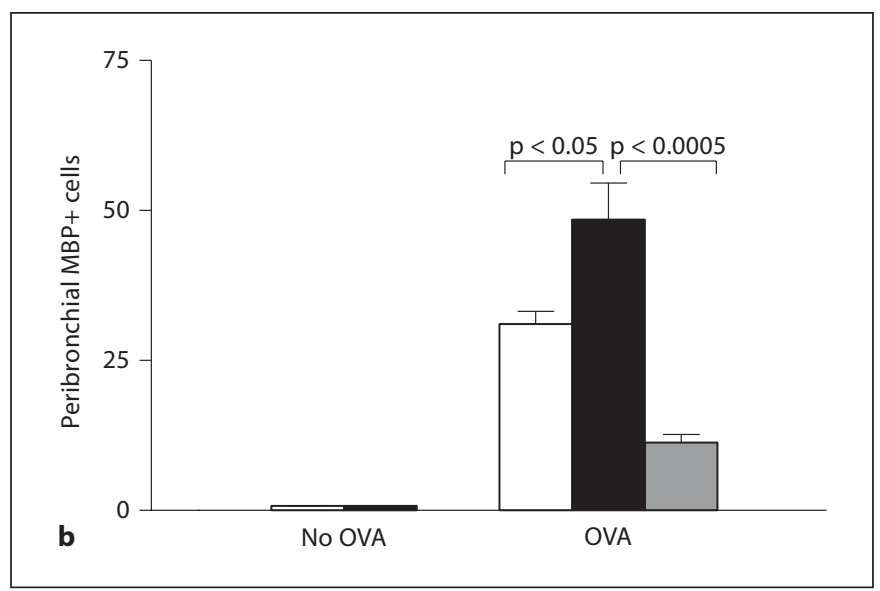

phils ( $<<0.0005$; ETS + OVA + ISS vs. ETS + OVA) (a) and peribronchial eosinophils $(\mathrm{p}<0.0005$; ETS + OVA + ISS vs. ETS + OVA) (b).
Thickness of the Peribronchial Smooth Muscle Layer. The thickness of the airway smooth muscle layer (the transverse diameter) was measured from the innermost aspect to the outermost aspect of the smooth muscle layer [28]. The smooth muscle layer thickness in at least 10 bronchioles of similar size $(150-200 \mu \mathrm{m})$ was calculated on each slide. Lung sections were also immunostained with an anti- $\alpha$-smooth muscle actin primary antibody (SigmaAldrich). The area of $\alpha$-smooth muscle actin staining was outlined and quantified using a light microscope attached to an image analysis system as previously described [28]. Results are expressed as the area of $\alpha$-smooth muscle actin staining/ $\mu \mathrm{m}$ length of the basement membrane of bronchioles 150-200 $\mu \mathrm{m}$ of internal diameter.

Airway Hyperreactivity. AHR to methacholine (Mch) was assessed $24 \mathrm{~h}$ after the final chronic OVA and/or chronic ETS challenge (after 1 month of repetitive OVA \pm ETS challenges) in intubated and ventilated mice (flexiVent ventilator; Scireq, Montreal, Que., Canada) as previously described in this laboratory [29]. The frequency-independent airway resistance $\left(R_{a w}\right)$ was determined in mice exposed to nebulized PBS and Mch (3, 24 and $48 \mathrm{mg} / \mathrm{ml}$ ) [29]. In addition to measuring $\mathrm{R}_{\mathrm{aw}}$, the Scireq software also recorded tissue elastance $\left(\mathrm{cm} \mathrm{H}_{2} \mathrm{O} \cdot \mathrm{s} / \mathrm{ml}\right)$ and compliance $\left(\mathrm{ml} / \mathrm{cm} \mathrm{H}_{2} \mathrm{O}\right)$.

Lung Levels of Th2 Cytokines and TGF- $\beta_{1}$

Levels of Th2 cytokines (IL-5, IL-13) and TGF- $\beta_{1}$ were measured in BAL by ELISA (R\&D Systems, Inc., Minneapolis, Minn., USA). The IL-5 assay has a sensitivity of $15 \mathrm{pg} / \mathrm{ml}$ while the IL-13 and TGF- $\beta_{1}$ assays each have a sensitivity of $31 \mathrm{pg} / \mathrm{ml}$.

Percentage Reduction in Inflammation and Remodeling in Response to ISS Therapy

To calculate the percentage reduction in individual indices of airway inflammation and remodeling in response to ISS therapy, the absolute increase in each of these indices in response to OVA
+ ETS was calculated according to the formula: (OVA + ETS) - (no OVA + ETS). This value is the maximum increase induced by OVA + ETS above baseline values. The reduction of this value induced by ISS therapy was calculated as a percentage.

\section{Statistical Analysis}

Results in the different groups of mice were compared by ANOVA using the nonparametric Kruskal-Wallis test followed by posttesting using Dunn's multiple comparison of means. All results are presented as mean \pm SEM. A statistical software package (GraphPad Prism; GraphPad Software, San Diego, Calif., USA) was used for the analysis. $\mathrm{p}<0.05$ was considered statistically significant.

\section{Results}

\section{Effect of ETS on OVA-Induced Airway Inflammation,} Airway Remodeling and $A H R$

Exposure of mice to chronic ETS alone did not induce an increase in BAL eosinophils (fig. 2a), $\mathrm{MBP}+$ peribronchial eosinophils (fig. $2 b$ ), TGF- $\beta_{1}+$ cells (fig. $3 a$ ), peribronchial fibrosis (fig. 3b, 4), thickness of the peribronchial smooth muscle layer (fig. 5), AHR (fig. 6a) and mucus production (fig. 7) compared to non-ETS-exposed mice as previously reported in this laboratory [26]. In contrast, chronic ETS in combination with chronic OVA allergen significantly increased all the indices of airway inflammation (fig. 2), airway remodeling (fig. 3b, 4, 5) and AHR (fig. 6a) compared to chronic OVA allergen alone as previously demonstrated in this laboratory [26]. 


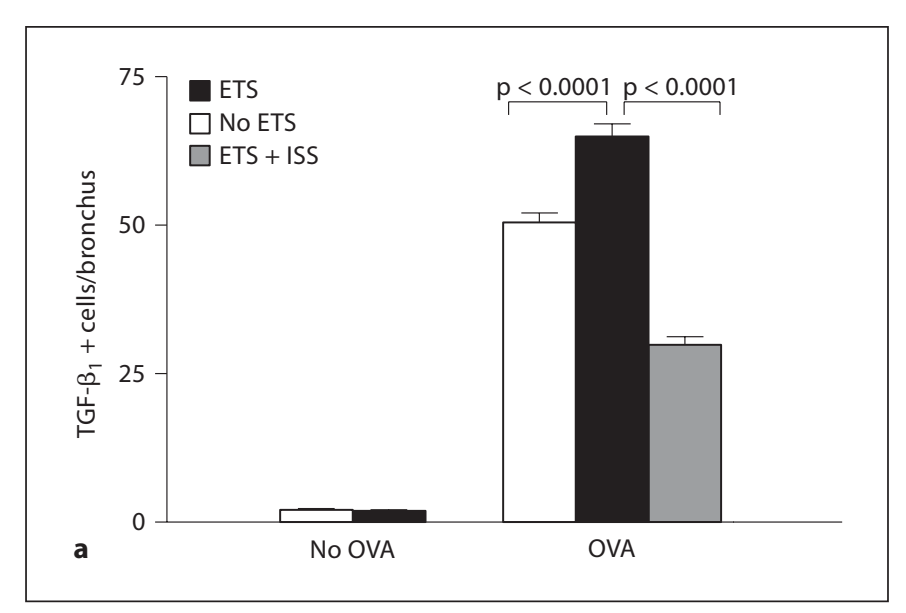

Fig. 3. a The number of peribronchial cells immunostaining positive for TGF- $\beta_{1}$ in mouse lungs was quantitated by image analysis. In ETS-exposed mice challenged with OVA, ISS significantly reduced the number of peribronchial cells immunostaining positive for TGF- $\beta_{1}(\mathrm{p}<0.0001$; ETS + OVA + ISS vs. ETS + OVA $)$

\section{Effect of TLR-9 Ligand on ETS + OVA-Induced}

Eosinophilic Airway Inflammation

Administration of ISS to mice exposed to chronic ETS + OVA allergen significantly reduced levels of BAL eosinophils by approximately $85 \%$ compared to chronic ETS + OVA allergen-challenged mice that did not receive ISS (ETS + OVA vs. ETS + OVA + ISS; p <0.0005) (fig. 2a). Similarly, administration of ISS to mice exposed to chronic ETS + OVA allergen significantly reduced levels of peribronchial MBP+ eosinophils by approximately $78 \%$ compared to chronic ETS + OVA allergen-challenged mice that did not receive ISS (ETS + OVA vs. ETS + OVA + ISS; $\mathrm{p}<0.0005)$ (fig. 2b).

\section{Effect of TLR-9 Ligand on ETS + OVA-Induced \\ Peribronchial TGF- $\beta_{1}+$ Cells}

Administration of ISS to mice exposed to chronic ETS + OVA allergen significantly reduced the number of peribronchial TGF- $\beta_{1}+$ cells by approximately $72 \%$ compared to chronic ETS + OVA allergen-challenged mice that did not receive ISS (ETS + OVA vs. ETS + OVA + ISS; p < 0.0001) (fig. 3a).

\section{Effect of TLR-9 Ligand on ETS + OVA-Induced \\ Peribronchial Fibrosis}

Administration of ISS to mice exposed to chronic ETS + OVA allergen significantly reduced the area of peribronchial trichrome staining by approximately $44 \%$ compared to chronic ETS + OVA allergen-challenged mice

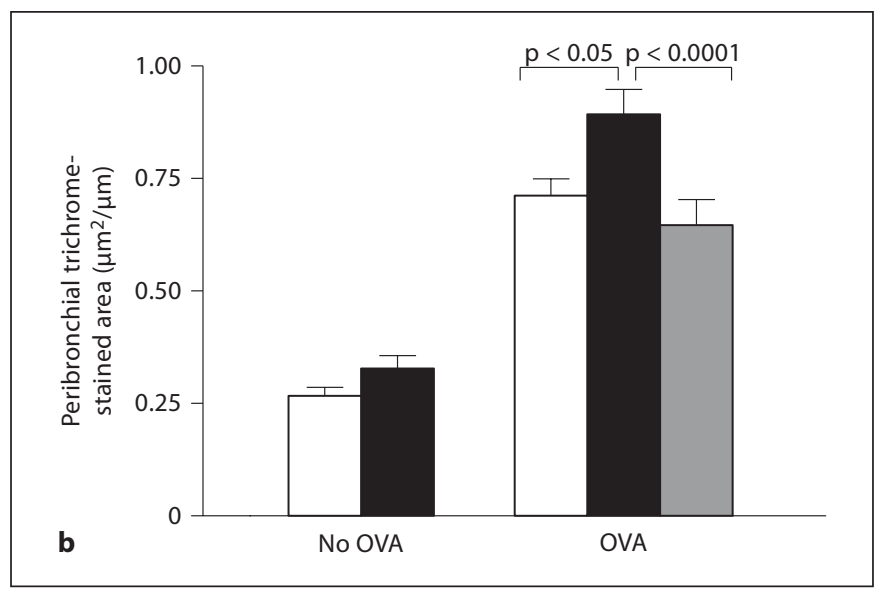

b The area of peribronchial trichrome staining in mouse lungs was quantitated in $\mu \mathrm{m}^{2} / \mu \mathrm{m}$ length of bronchus by image analysis. In ETS-exposed mice challenged with OVA, ISS significantly reduced the area of peribronchial trichrome staining $(p<0.0001$; ETS + OVA + ISS vs. ETS + OVA).

that did not receive ISS (ETS + OVA vs. ETS + OVA + ISS; $\mathrm{p}<0.0001$ ) (fig. 3b, 4).

\section{Effect of TLR-9 Ligand on ETS + OVA-Induced}

Thickness of Peribronchial Smooth Muscle Layer

Administration of ISS to mice exposed to chronic ETS + OVA allergen significantly reduced the thickness of the peribronchial smooth muscle layer by approximately $53 \%$ compared to chronic ETS + OVA allergen-challenged mice that did not receive ISS (ETS + OVA vs. ETS + OVA + ISS; $\mathrm{p}<0.0001$ ) (fig. 5a).

In addition to measuring the thickness of the smooth muscle layer, we also determined the area of peribronchial $\alpha$-smooth muscle actin immunostaining. Administration of ISS to mice exposed to chronic ETS + OVA allergen significantly reduced the area of peribronchial $\alpha$ smooth muscle actin immunostaining by approximately $49 \%$ compared to chronic ETS + OVA allergen-challenged mice that did not receive ISS (ETS + OVA vs. ETS + OVA + ISS; $\mathrm{p}<0.0001$ ) (fig. 5b).

\section{Effect of TLR-9 Ligand on ETS + OVA-Induced AHR}

Administration of ISS to mice exposed to chronic ETS + OVA allergen significantly reduced AHR compared to chronic ETS + OVA allergen-challenged mice that did not receive ISS (ETS + OVA vs. ETS + OVA + ISS; Mch $48 \mathrm{mg} /$ $\mathrm{ml} ; \mathrm{p}=0.04$ ) (fig. 6a). Administration of ISS also reduced tissue elastance in OVA + ETS-challenged mice $(\mathrm{p}<0.05 ; \mathrm{Mch} 48 \mathrm{mg} / \mathrm{ml} ; \mathrm{ETS}+$ OVA + ISS vs. ETS + OVA $)$ 
Fig. 4. Lungs from the 5 groups of mice (no OVA, no OVA + ETS, OVA, OVA + ETS, OVA + ETS + ISS) were processed for trichrome staining to detect peribronchial fibrosis (blue) and for PAS staining to detect epithelial mucus expression.

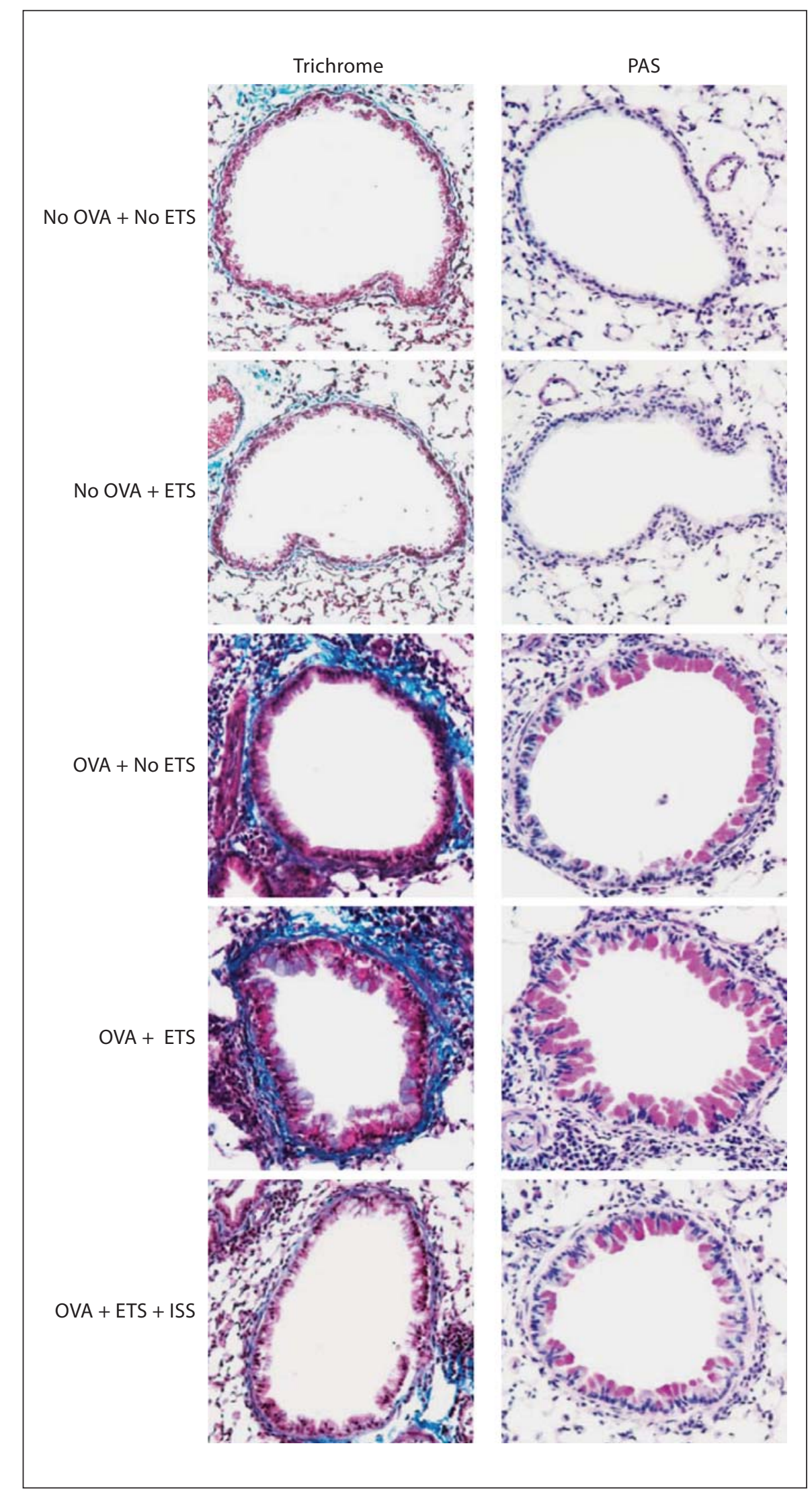

Song/Min/Miller/Cho/Yum/Broide 


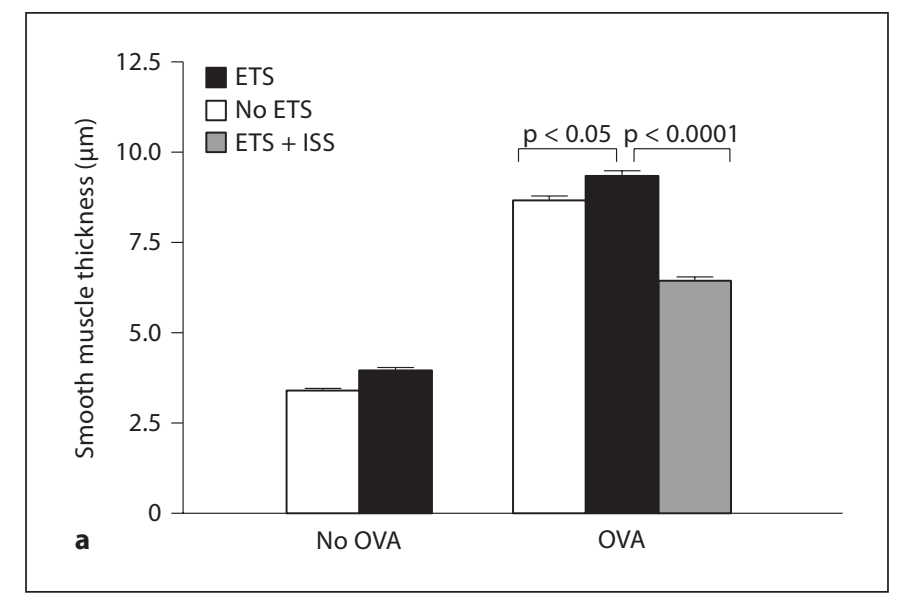

Fig. 5. a The thickness of peribronchial smooth muscle layer was assessed by image analysis. $\mathbf{b}$ The area of the peribronchial region immunostaining positive with $\alpha$-smooth muscle actin antibody was quantitated by image analysis $\left(\mu \mathrm{m}^{2} / \mu \mathrm{m}\right.$ length of the basement membrane of the bronchus). In ETS-exposed mice challenged with OVA, ISS significantly reduced both the thickness of

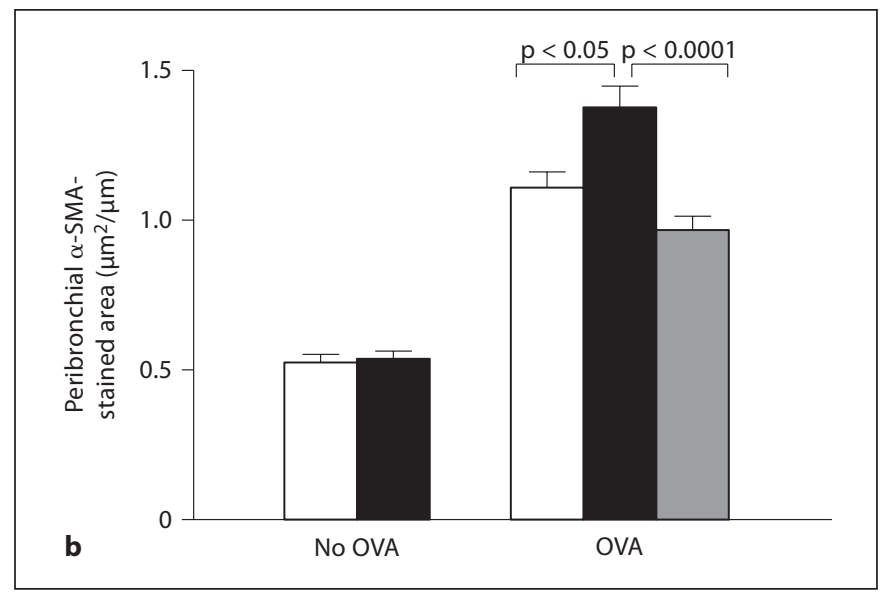

the peribronchial smooth muscle layer $(\mathrm{p}<0.0001$; ETS + OVA + ISS vs. ETS + OVA) (a) and the area of the peribronchial region immunostaining positive with $\alpha$-smooth muscle actin antibody $(\mathrm{p}<0.0001 ; \mathrm{ETS}+\mathrm{OVA}+\mathrm{ISS}$ vs. ETS + OVA $)(\mathbf{b})$. SMA = Smooth muscle actin.

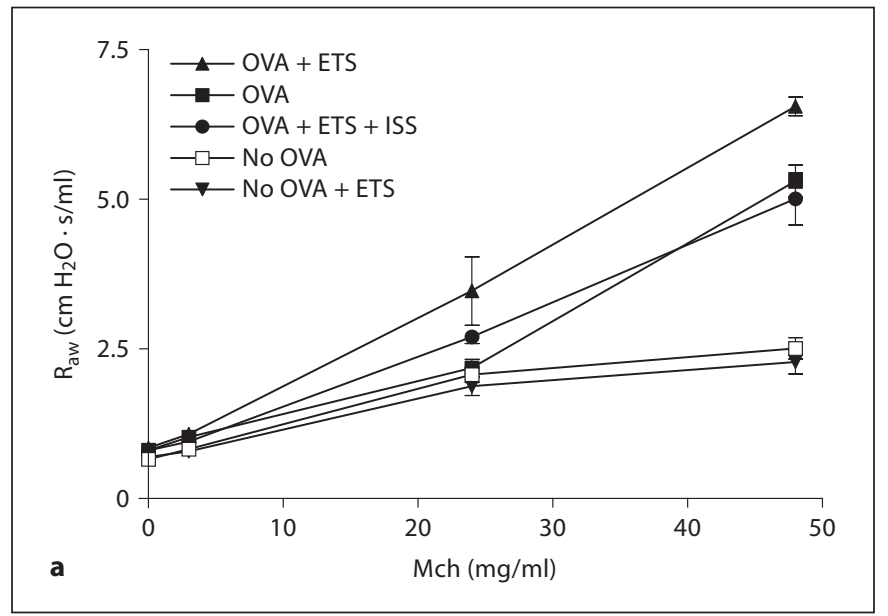

Fig. 6. a AHR to Mch was assessed $24 \mathrm{~h}$ after final chronic OVA and/or chronic ETS challenge in intubated and ventilated mice. Results are expressed as $\mathrm{R}_{\mathrm{aw}}$ in mice exposed to nebulized Mch (3, 24 and $48 \mathrm{mg} / \mathrm{ml}$ ). In ETS-exposed mice challenged with OVA, ISS significantly reduced AHR ( $<<0.04$; Mch $48 \mathrm{mg} / \mathrm{ml}$; ETS + OVA + ISS vs. ETS + OVA). ISS also reduced tissue elastance in OVA + ETS-challenged mice ( $\mathrm{p}<0.05$; Mch $48 \mathrm{mg} / \mathrm{ml})$ (b) and improved compliance ( $\mathrm{p}<0.001$; Mch $48 \mathrm{mg} / \mathrm{ml}$; ETS + OVA + ISS vs. ETS + OVA) (c).
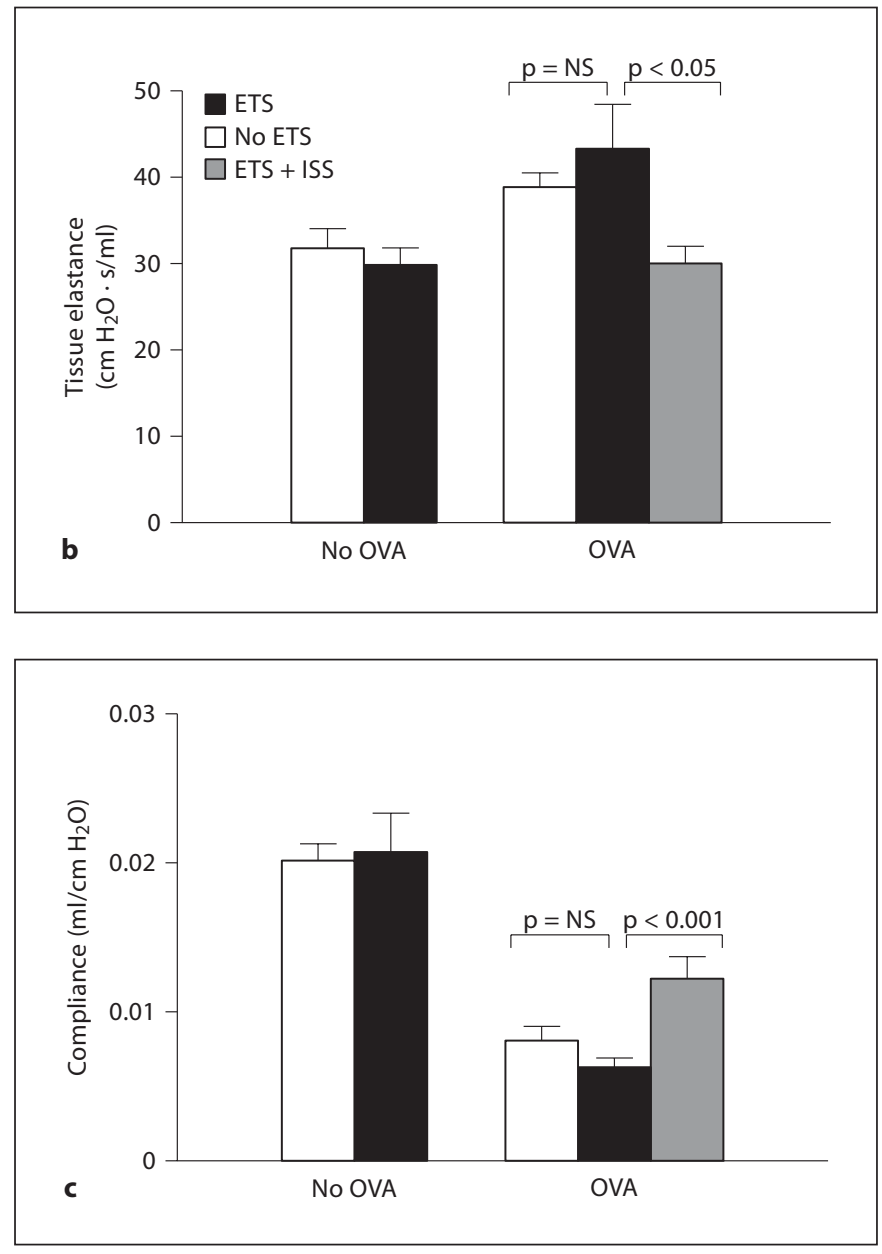

Int Arch Allergy Immunol 2010;151:285-296 


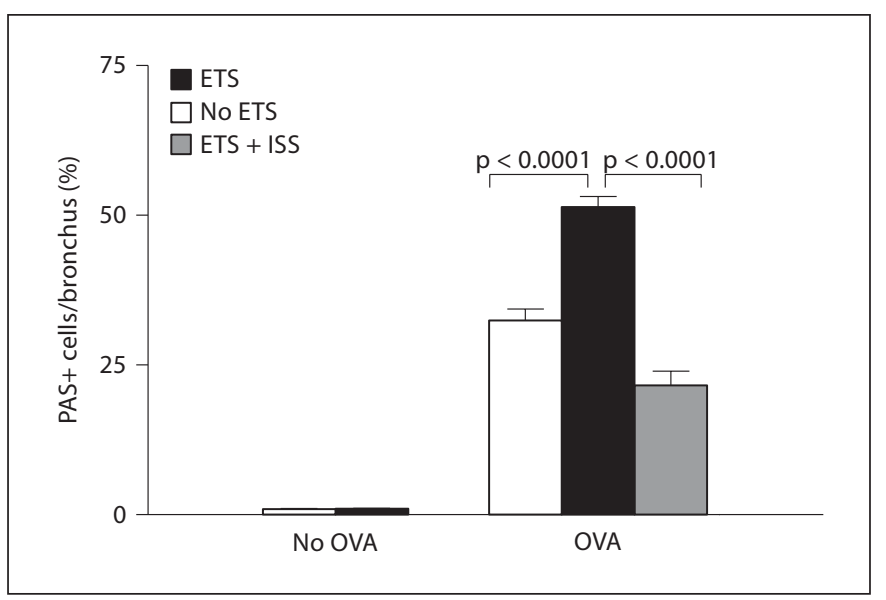

Fig. 7. The percentage of bronchial epithelial cells staining positive for PAS was quantitated by light microscopy. In ETS-exposed mice challenged with OVA, ISS significantly reduced the percentage of PAS+ airway epithelial cells $(\mathrm{p}<0.0001$; ETS + OVA + ISS vs. ETS + OVA)

(fig. 6b) and improved compliance ( $\mathrm{p}<0.001 ;$ Mch $48 \mathrm{mg} /$ ml; ETS + OVA + ISS vs. ETS + OVA) (fig. 6c).

\section{Effect of TLR-9 Ligand on ETS + OVA-Induced Mucus} Expression

Administration of ISS to mice exposed to chronic ETS + OVA allergen significantly reduced levels of mucus expression by approximately $58 \%$ compared to chronic ETS + OVA allergen-challenged mice that did not receive ISS (ETS + OVA vs. ETS + OVA + ISS; p < 0.0001) (fig. 7).

\section{Effect of TLR-9 Ligand on ETS + OVA-Induced Lung} Th2 Cytokines (IL-5, IL-13) and TGF- $\beta_{1}$

Administration of ISS to mice exposed to chronic ETS + OVA allergen significantly reduced levels of BAL IL-5 (fig. 8a), BAL IL-13 (fig. 8b) and TGF- $\beta_{1}$ (fig. 8c) compared to chronic ETS + OVA allergen-challenged mice that did not receive ISS (ETS + OVA vs. ETS + OVA + ISS; $\mathrm{p}<0.05)$.

\section{Discussion}

In this study we demonstrated that a TLR-9 agonist (i.e. ISS) is very effective in reducing ETS-enhanced eosinophilic airway inflammation, airway remodeling and AHR in mice exposed to the combination of chronic ETS and chronic OVA allergen. In mice coexposed to ETS and OVA, the TLR-9 agonist inhibited the expression of cyto- kines that contribute to eosinophilic inflammation (i.e. IL-5), AHR (i.e. IL-13) and airway remodeling (i.e. TGF$\beta_{1}$ ). Previous studies from our $[12,26]$ and other laboratories $[13,14]$ have demonstrated an enhanced Th2 response to the combination of ETS and allergen as opposed to either stimulus alone. However, the demonstration that a TLR-9 agonist inhibits enhanced airway inflammation, remodeling and AHR in mice exposed to OVA + ETS is novel and most likely due to the ability of TLR-9-based therapies to inhibit Th2 responses to allergen [19], which are enhanced in mice coexposed to allergen and ETS $[12,26]$ and reduced in those mice administered the TLR-9 ligand. As corticosteroids exhibit a reduced anti-inflammatory effectiveness in smokers [15-18], it is important to identify therapeutic interventions that inhibit Th2 responses in the presence of ETS. In addition to having anti-inflammatory properties, ISS also inhibited airway remodeling in ETS-exposed mice. Studies have shown that smokers with asthma have a more rapid decline in lung function as compared to nonsmokers with asthma [2]. Thus, there is also a need to identify novel therapeutic interventions that inhibit airway remodeling in smokers. In mice exposed to allergen + ETS, the increased numbers of cells expressing TGF- $\beta_{1}$ may contribute to airway remodeling as several [30-32], but not all [33], studies in mice in which TGF- $\beta_{1}$ signaling is inhibited demonstrate reduced airway remodeling. Thus, the ability of ISS to significantly reduce levels of lung TGF- $\beta_{1}$ as well as the numbers of peribronchial cells expressing TGF- $\beta_{1}$, such as eosinophils, in mice exposed to ETS + allergen may contribute to a reduction in levels of airway remodeling and airway responsiveness. However, as TLR-9-based therapies influence several different cell types which express TLR-9, the resultant inhibit effects on remodeling and airway responsiveness may, or may not, be linked.

This study extends previous observations that ISS is able to inhibit inflammation, remodeling and AHR in mice exposed to allergen alone [19-24] to demonstrate that ISS can inhibit these asthma outcomes in mice exposed to the combination of ETS and allergen who have enhanced inflammation, remodeling and AHR. As we have previously demonstrated that ISS inhibits these airway inflammation and remodeling outcomes in nonETS-exposed OVA-challenged mice [21], we did not include a group of ISS-treated, OVA-challenged, non-ETSexposed mice in this study. Although the lack of a control ISS + OVA group is a limitation of our study, in comparing results of ISS therapy in this ETS + OVA exposure study to previous studies of ISS in non-ETS-exposed 

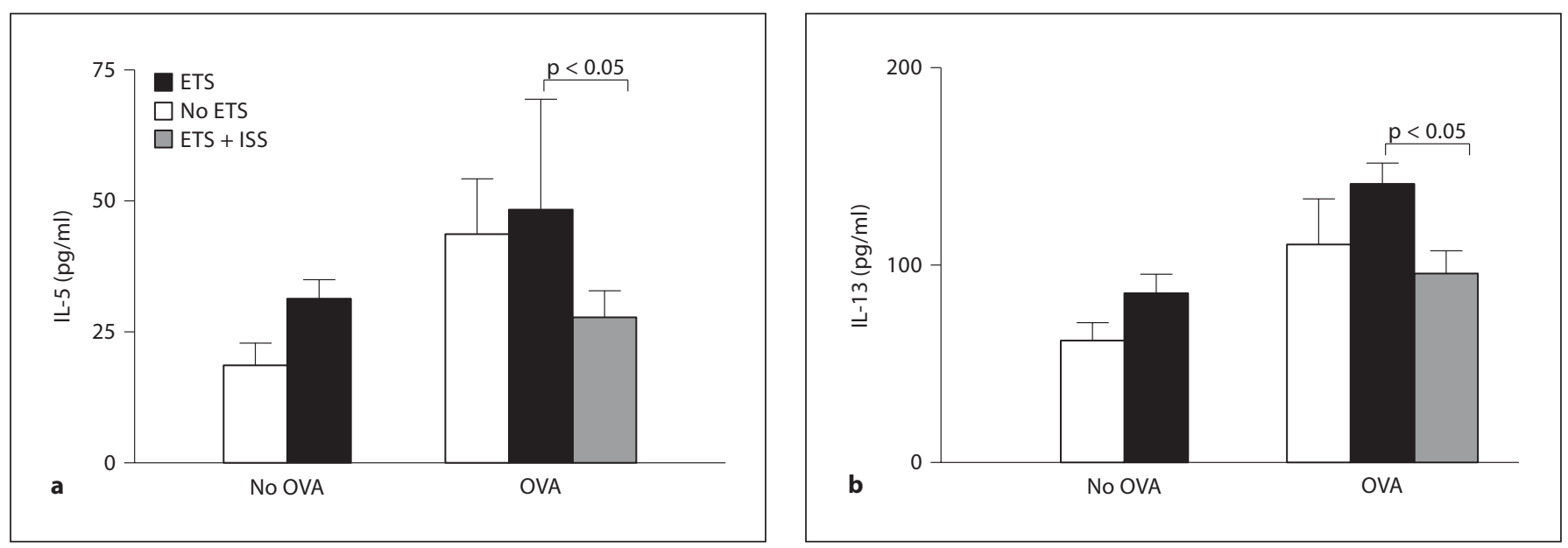

Fig. 8. Levels of Th2 cytokines (IL-5, IL-13) and TGF- $\beta_{1}$ in BAL were measured by ELISA. Administration of ISS to mice exposed to chronic ETS + OVA allergen significantly reduced levels of IL5 (a), IL-13 (b) and TFG- $\beta_{1}$ (c) compared to chronic ETS + OVAchallenged mice that did not receive ISS $(\mathrm{p}<0.05$; ETS + OVA vs. ETS + OVA + ISS).

mice, we demonstrated that ISS inhibited airway inflammation and remodeling in mice exposed to ETS + OVA as effectively as in previous studies in which OVA-exposed mice were treated with ISS in the absence of ETS exposure [21]. For example, comparing the levels of inhibition of the indices of airway inflammation and airway remodeling in the current study to those of previous studies by our group [21] demonstrates that ISS induced comparable levels of inhibition of BAL eosinophilia (85 vs. $63 \%$ ) [21], a reduction in smooth muscle thickness (53 vs. $45 \%$ ) and a reduction in the number of PAS+ cells (58 vs. $64 \%)$. In addition, in the present study ISS reduced OVA + ETS-induced airway inflammation and remodeling to levels significantly below that of untreated mice exposed to OVA alone (OVA + no ETS + no ISS vs. OVA + ETS + ISS), suggesting that ISS was impacting both the OVA as well as the OVA + ETS effect on inflammation and remodeling. These observations, demonstrating the poten-

tial therapeutic utility of ISS in ETS-exposed mice, are potentially important to the large number of asthmatic children and adults exposed to ETS, in whom ETS exposure is associated with adverse asthma outcomes $[6,7,34]$. The large number of asthmatics exposed to ETS has been noted in pediatric and adult studies $[6,7,34]$. For example, approximately $68 \%$ of nonsmoking urban children aged 8-14 years had evidence of ETS exposure as assessed by salivary cotinine levels [7] while approximately $29 \%$ of nonsmoking adult asthmatics aged $18-50$ years in California reported some regular ETS exposure (defined as most days or nights) during an 18-month study period [34]. The ETS-exposed asthmatics had increased asthma severity, increased health care utilization for asthma (emergency department visits, urgent physician visits and hospitalizations) and worse asthma-specific quality of life [34]. The asthmatics who reported cessation of ETS exposure over the 18-month study experienced a reduc- 
tion in asthma severity and decreased health care utilization consistent with improved asthma [34]. Conversely, asthmatics with newly initiated significant exposure to ETS over the follow-up period had worsening of asthma severity and asthma-specific quality of life measures [34]. Overall, these studies suggest an important role of ETS in asthma severity and quality of life.

Our study, using a mouse model, has the advantage of being able to accurately provide a well-defined level of exposure to ETS to determine whether ISS is effective in the presence of ETS. The mouse model also demonstrates that this level of ETS exposure has a biological effect in enhancing levels of airway inflammation, mucus, airway remodeling and AHR. The limitation of our study, as with all studies in mouse models, is that it is unknown how the results in the mouse model will translate to the effect of ISS in humans with asthma exposed to ETS. Further studies are also needed to determine whether ISS is effective in inhibiting asthmatic responses at higher doses of tobacco smoke exposure as noted in current smokers. As TLR agonists other than TLR-9 (TLR-2, TLR-4 and TLR-7/8) have inhibitory [35-37] or potentiating effects $[38,39]$ on inflammation and AHR in OVA models depending upon the timing and route of administration of the TLR agonist, further study is needed to determine the effect of individual TLR agonists other than TLR-9 in mice exposed to OVA + ETS. Prior studies have also demonstrated increased levels of lipopolysaccharide (LPS) in IRF4 cigarettes (approximately 17,800 ng LPS/cigarette) as compared to mainstream smoke (approximately 120 ng LPS/cigarette), and considerably lower levels of LPS in ETS (approximately $18 \mathrm{ng}$ LPS/cigarette) [40]. As the OVA + ETS as well as the OVA + ETS + ISS groups were both exposed to the same ETS (with potentially small amounts of LPS in the ETS), this is very unlikely to account for differences in asthma outcomes observed between these groups of mice.
At present there are limited numbers of studies investigating the therapeutic efficacy of ISS in humans with allergy and asthma. Studies of ISS conjugated to the major ragweed allergen Amb a 1 have demonstrated that in humans with allergic rhinitis the conjugate inhibits Th2 cytokine production by peripheral blood mononuclear cells in vitro [41-43] as well as by cells in the nasal mucosa in response to allergen challenge in vivo [44]. The ISS-Amb a 1 conjugate also inhibits symptoms during the fall ragweed season in subjects with allergic rhinitis [25]. In limited studies in mild asthmatics utilizing an allergen challenge study design, nebulized ISS did not reduce the number of sputum eosinophils or the late-phase response to allergen challenge [45]. Thus, further studies are needed to determine whether ISS, which has demonstrated therapeutic efficacy in mouse [19-24] and primate models of asthma [46], is effective in humans with asthma.

In summary, using a mouse model, our studies demonstrate that ISS significantly reduces levels of eosinophilic airway inflammation, mucus expression, airway remodeling and AHR in mice exposed to the combination of ETS and allergen. However, further human studies are needed to determine whether similar results would be observed in asthmatics treated with ISS who are exposed to ETS. Results from such human studies may be of particular importance to the large number of asthmatics exposed to ETS who have adverse asthma outcomes, as well as to children with the 17q21 gene variant who are at increased risk of developing asthma on exposure to ETS in early childhood [8].

\section{Acknowledgments}

This study was supported by a Tobacco-Related Disease Research Program (TRDRP) grant 12RT-0071 (D.H.B.) and National Institutes of Health (NIH) grants AI 38425, AI 70535 and AI 72115 (D.H.B.).

\section{References}

1 Busse WW, Lemanske R Jr: Asthma. N Engl J Med 2001;344:350-362.

-2 Lange P, Parner J, Vestbo J, Schnohr P, Jensen G: A 15-year follow-up study of ventilatory function in adults with asthma. N Engl J Med 1998;339:1194-1200.

-3 Silverman RA, Boudreaux ED, Woodruff PG, Clark S, Camargo CA: Cigarette smoking among asthmatic adults presenting to 64 emergency departments. Chest 2003; 123 : $1472-1479$.
4 Chaudhuri R, Livingston W, McMahon AD, Lafferty J, Fraser I, Spears M, McSharry CP, Thomson NC: Effects of smoking cessation on lung function and airway inflammation in smokers with asthma. Am J Respir Crit Care Med 2006;174:127-133.

5 Chilmonczyk BA, Salmun LM, Megathlin KN, Neveux LM, Palomaki GE, Knight GJ, Pulkkinen AJ, Haddow JE: Association between exposure to environmental tobacco smoke and exacerbations of asthma in children. N Engl J Med 1993;328:1665-1669.
-6 Eisner MD, Klein J, Hammond SK, Koren G, Lactao G, Iribarren C: Directly measured second hand smoke exposure and asthma health outcomes. Thorax 2005;60:814-821.

7 Kumar R, Curtis LM, Khiani S, Moy J, Shalowitz MU, Sharp L, Durazo-Arvizu RA, Shannon JJ, Weiss KB: A community-based study of tobacco smoke exposure among inner-city children with asthma in Chicago. J Allergy Clin Immunol 2008;122:754-759. 
$>8$ Bouzigon E, Corda E, Aschard H, Dizier $\mathrm{MH}$, Boland A, Bousquet J, Chateigner N, Gormand F, Just J, le Moual N, Scheinmann P, Siroux V, Vervloet D, Zelenika D, Pin I, Kauffmann F, Lathrop M, Demenais F: Effect of 17q21 variants and smoking exposure in early-onset asthma. N Engl J Med 2008; 359:1985-1994.

$\checkmark 9$ Menon P, Rando RJ, Stankus RP, Salvaggio JE, Lehrer SB: Passive cigarette smoke-challenge studies: increase in bronchial hyperreactivity. J Allergy Clin Immunol 1992;89: 560-566.

10 Stankus RP, Menon PK, Rando RJ, Glindmeyer H, Salvaggio JE, Lehrer SB: Cigarette smoke-sensitive asthma: challenge studies. J Allergy Clin Immunol 1988;82:331-338.

$\checkmark 11$ Centers for Disease Control and Prevention (CDC): Cigarette smoking among adults: United States, 2000. MMWR Morb Mortal Wkly Rep 2002;51:642-645.

12 Min MG, Song DJ, Miller M, McElwain S, Ferguson P, Broide DH: Coexposure to environmental tobacco smoke increases levels of allergen-induced airway remodeling in mice. J Immunol 2007;178:5321-5328.

-13 Seymour BW, Pinkerton KE, Friebertshauser KE, Coffman RL, Gershwin LJ: Secondhand smoke is an adjuvant for Th2 responses in a murine model of allergy. J Immunol 1997;159:6169-6175.

14 Rumold R, Jyrala M, Diaz-Sanchez DD: Second-hand smoke induces allergic sensitization in mice. J Immunol 2001;167:47654770 .

-15 Chalmer GW, Macleod KJ, Little SA, Thomson LJ, McSharry CP, Thomson NC: Influence of cigarette smoking on inhaled corticosteroid treatment in mild asthma. Thorax 2002;57:226-230.

-16 Lazarus SC, Chinchilli VM, Rollings NJ, Boushey HA, Cherniack R, Craig TJ, Deykin A, DiMango E, Fish JE, Ford JG, Israel E, Kiley J, Kraft M, Lernanske RF, Leone FT, Martin RJ, Pesola GR, Peters SP, Sorkness CA, Szefler SJ, Wechsler ME, Fahy JV, National Heart, Lung, and Blood Institute's Asthma Clinical Research Network: Smoking affects response to inhaled corticosteroids or leukotriene receptor antagonists in asthma. Am J Respir Crit Care Med 2007;175:783-790.

$\checkmark 17$ Tomlinson JE, McMahon AD, Chaudhuri R, Thompson JM, Wood SF, Thomson NC: Efficacy of low and high dose inhaled corticosteroid in smokers versus non-smokers with mild asthma. Thorax 2005;60:282-287.

18 Chaudhuri R, Livingston E, McMahon AD, Thomson L, Borland W, Thomson NC: Cigarette smoking impairs the therapeutic response to oral corticosteroids in chronic asthma. Am J Respir Crit Care Med 2003; 168:1308-1311.
19 Broide D, Schwarze J, Tighe H, Gifford T, Nguyen MD, Malek S, van Uden J, MartinOrozco E, Gelfand EW, Raz E: Immunostimulatory DNA sequences inhibit IL-5, eosinophilic inflammation, and airway hyperresponsiveness in mice. J Immunol 1998;161: 7054-7062.

-20 Ikeda RK, Miller M, Nayar J, Walker L, Cho JY, McElwain K, McElwain S, Raz E, Broide DH: Accumulation of peribronchial mast cells in a mouse model of ovalbumin allergen induced chronic airway inflammation: modulation by immunostimulatory DNA sequences. J Immunol 2003;171:4860-4867.

21 Cho J, Miller M, Baek K, Han JW, Nayar J, Rodriguez M, Lee SY, McElwain K, McElwain S, Raz E, Broide DH: Immunostimulatory DNA inhibits transforming growth factor- $\beta$ expression and airway remodeling. Am J Respir Cell Mol Biol 2004;30:651-661.

-22 Cho JY, Miller M, Baek KJ, Han JW, Nayar J, Lee SY, McElwain K, McElwain S, Raz E, Broide DH: Immunostimulatory DNA reverses established allergen-induced airway remodeling. J Immunol 2004; 173:75567564.

23 Lee SY, Cho JY, Miller M, McElwain K, McElwain S, Sriramarao P, Raz E, Broide DH: Immunostimulatory DNA inhibits allergen-induced peribronchial angiogenesis in mice. J Allergy Clin Immunol 2006;117: 597-603.

24 Cho JY, Miller M, McElwain K, McElwain S, Shim JY, Raz E, Broide DH: Remodeling associated expression of matrix metalloproteinase 9 but not tissue inhibitor of metalloproteinase 1 in airway epithelium: modulation by immunostimulatory DNA. J Allergy Clin Immunol 2006;117:618-625.

25 Creticos PS, Schroeder JT, Hamilton RG, Balcer-Whaley SL, Khattignavong AP, Lindblad R, Li H, Coffman R, Seyfert V, Eiden JJ, Broide D, Immune Tolerance Network: Immunotherapy with a ragweed-toll-like receptor 9 agonist vaccine for allergic rhinitis. N Engl J Med 2006;355:1445-1455.

26 Song DJ, Min MG, Miller M, Cho JY, Broide DH: Environmental tobacco smoke exposure does not prevent corticosteroids reducing inflammation, remodeling, and airway hyperreactivity in mice exposed to allergen. Am J Physiol Lung Cell Mol Physiol 2009; 297:L380-L387.

27 Broide DH, Stachnick G, Castandeda D, Nayar J, Miller M, Cho JY, Roman M, Zubeldia J, Hayashi T, Raz E: Systemic administration of immunostimulatory SNA sequences mediates reversible inhibition of Th2 responses in a mouse model of asthma. J Clin Immunol 2001;21:175-182.

28 Miller M, Cho JY, McElwain K, McElwain S, Shim JY, Manni M, Baek JS, Broide DH: Corticosteroids prevent myofibroblast accumulation and airway remodeling in mice. Am J Physiol Lung Cell Mol Physiol 2006;290: L162-L169.
29 Lim DH, Cho JY, Song DJ, Lee SY, Miller M, Broide DH: PI3K gamma-deficient mice have reduced levels of allergen-induced eosinophilic inflammation and airway remodeling. Am J Physiol Lung Cell Mol Physiol 2009;296:L210-L219.

-30 Le AV, Cho JY, Miller M, McElwain S, Golgotiu K, Broide DH: Inhibition of allergeninduced airway remodeling in Smad 3-deficient mice. J Immunol 2007;178:7310-7316.

31 McMillan SJ, Xanthou G, Lloyd CM: Manipulation of allergen-induced airway remodeling by treatment with anti-TGF-beta antibody: effect on the Smad signaling pathway. J Immunol 2005;174:5774-5780.

32 Alcorn J, Rinaldi L, Jaffe E, van Loon M, Bates J, Janssen-Heininger Y, Irvin C: Transforming growth factor- $\beta_{1}$ suppresses airway hyperresponsiveness in allergic airway disease. Am J Respir Crit Care Med 2007;176: 974-982.

33 Fattouh R, Midence G, Arias K, Johnson J, Walker T, Goncharova S, Souza K, Gregory R, Lonning S, Gauldie J, Jordana M: Transforming growth factor- $\beta$ regulates house dust mite-induced allergic airway inflammation but not airway remodeling. Am J Respir Crit Care Med 2008;177:593-603.

34 Eisner MD, Yelin EH, Henke J, Shiboski SC, Blanc PD: Environmental tobacco smoke and adult asthma: the impact of changing exposure status on health outcomes. Am J Respir Crit Care Med 1998;158:170-175.

-35 Akdis CA, Kussebi F, Pulendran B, Akdis M, Lauener RP, Schmidt-Weber CB, Klunker S, Isitmangil G, Hansjee N, Wynn TA, Dillon S, Erb P, Baschang G, Blaser K, Alkan SS: Inhibition of $\mathrm{T}$ helper 2-type responses, IgE production and eosinophilia by synthetic lipopeptides. Eur J Immunol 2003;33:27172726.

>36 Tulić MK, Wale JL, Holt PG, Sly PD: Modification of the inflammatory response to allergen challenge after exposure to bacterial lipopolysaccharide. Am J Respir Cell Mol Biol 2000;22:604-612.

-37 Camateros P, Tamaoka M, Hassan M, Marino R, Moisan J, Marion D, Guiot MC, Martin JG, Radzioch D: Chronic asthma-induced airway remodeling is prevented by toll-like receptor-7/8 ligand S28463. Am J Respir Crit Care Med 2007;175:1241-1249.

$>38$ Lefort J, Singer M, Leduc D, Renesto P, Nahori MA, Huerre M, Créminon C, Chignard M, Vargaftig BB: Systemic administration of endotoxin induces bronchopulmonary hyperreactivity dissociated from TNF-alpha formation and neutrophil sequestration into the murine lungs. J Immunol 1998;161:474480 .

39 Redecke V, Häcker H, Datta SK, Fermin A, Pitha PM, Broide DH, Raz E: Cutting edge: activation of toll-like receptor 2 induces a Th2 immune response and promotes experimental asthma. J Immunol 2004;172:27392743. 
-40 Hasday JD, Bascom R, Costa JJ, Fitzgerald T, Dubin W: Bacterial endotoxin is an active component of cigarette smoke. Chest 1999; 115:829-835.

-41 Tighe H, Takabayashi K, Schwartz D, van Nest G, Tuck S, Eiden JJ, Kagey-Sobotka A, Creticos PS, Lichtenstein LM, Spiegelberg HL, Raz E: Conjugation of immunostimulatory DNA to the short ragweed allergen Amb a 1 enhances its immunogenicity and reduces its allergenicity. J Allergy Clin Immunol 2000;106:124-134.
2 Marshall JD, Abtahi S, Eiden J, Tuck S, Mil ley R, Haycock F, Reid MJ, Kagey-Sobotka A Creticos PS, Lichtenstein LM, van Nest G: Immunostimulatory sequence DNA linked to the Amb a 1 allergen promotes $\mathrm{T}_{\mathrm{H}} 1$ cytokine expression while downregulating $\mathrm{T}_{\mathrm{H}} 2$ cytokine expression in PBMCs from human patients with ragweed allergy. J Allergy Clin Immunol 2001;108:191-197.

43 Simons FE, Shikishima Y, van Nest G, Eiden JJ, HayGlass KT: Selective immune redirection in humans with ragweed allergy by injecting Amb a 1 linked to immunostimulatory DNA. J Allergy Clin Immunol 2004;113: 1144-1151.

-44 Tulic MK, Fiset PO, Christodoulopoulos P, Vaillancourt P, Desrosiers M, Lavigne F, Eiden J, Hamid Q: Amb a 1-immunostimulatory oligodeoxynucleotide conjugate immunotherapy decreases the nasal inflammatory response. J Allergy Clin Immunol 2004;113: 235-241.
45 Gauvreau GM, Hessel EM, Boulet LP, Coffman RL, O’Byrne PM: Immunostimulatory sequences regulate interferon-inducible genes but not allergic airway responses. Am J Respir Crit Care Med 2006;174:15-20.

46 Fanucchi MV, Schelegle ES, Baker GL, Evans MJ, McDonald RJ, Gershwin LJ, Raz E, Hyde DM, Plopper CG, Miller LA: Immunostimulatory oligonucleotides attenuate airways remodeling in allergic monkeys. Am J Respir Crit Care Med 2004;170:1153-1157. 